\title{
$\mathrm{PC}$ 기반 순음청력검사기를 위한 자동보정시스템 개발
}

김진동 ${ }^{1}$, 강덕훈 $^{2}$, 송복득 $^{2}$, 이일우 $^{3}$, 공수근 $^{3}$, 권순복 $^{4}$, 전계록 $^{1}$, 신범주 $^{2^{*}}$, 왕수건 ${ }^{3}$ ${ }^{1}$ 부산대학교 의학전문대학원 의공학교실, ${ }^{2}$ 부산대학교 바이오메디컬공학과,

${ }^{3}$ 부산대학교 의학전문대학원 이비인후과학교실, ${ }^{4}$ 부산대학교 인문대학 언어정보학과

\section{Development of Automatic Calibration System for PC-Based Pure Tone Audiometer}

\author{
Jin-Dong Kim ${ }^{1}$, Deok-Hun Kang², Bok-Deuk Song², Il-Woo Lee ${ }^{3}$, \\ Soo-Keun Kong ${ }^{3}$, Soon-Bok Kwon ${ }^{4}$, Gye-Rok Jeon ${ }^{1}$, \\ Bum-Joo Shin ${ }^{2 *}$ and Soo-Geun Wang ${ }^{3}$ \\ ${ }^{1}$ Department of Biomedical Engineering, School of Medicine, Pusan National University \\ ${ }^{2}$ Department of Biomedical Engineering, College of Natural Resource and Life Science, Pusan \\ National University \\ ${ }^{3}$ Department of Otolaryngology, School of Medicine, Pusan National University \\ ${ }^{4}$ Department of Linguistics College of Humanities, Pusan National University
}

요 약 순음청력검사기는 정확한 주파수와 음압을 갖는 순음과 차폐 음을 생성하여 출력할 수 있어야 한다. 이를 위해 일정한 기간마다 보정을 하는 것이 불가피하다. 그러나 수동 보정을 사용하는 일반 순음청력검사기의 음향 보정 은 집중력이 필요할 뿐 아니라 시간이 많이 걸리는 단점이 있다. 반면, $\mathrm{PC}$ 기반 순음청력검사기의 경우 소프트웨어를 이용하여 자동으로 보정을 수행하는 것이 가능하다. 본 논문에서는 PC 기반 순음청력검사기의 자동 보정을 지원하기 위해 PC 사운드카드를 이용하여 구현한 음압측정기와 이를 이용한 순음청력검사기의 자동보정모듈을 기술한다. 자동 보정모듈을 이용하여 보정한 PC 기반 순음청력검사기를 국제표준기구가 제공하는 기준등가역치음압수준과의 적합 여 부를 검증한다.

\begin{abstract}
A pure tone audiometer should be able to produce both pure tone and masking noise with exact sound pressure level and frequency. For such purpose, it is unavoidable to periodically calibrates pure tone audiometer. However, manual acoustic calibration requires not only attention but also long time. It is possible to execute automatically calibration using software if it is PC-based pure tone audiometer. In this paper, we describe auto-calibration software for PC-based pure tone audiometer and dedicated sound level meter which has been implemented upon PC by us. To verify auto-calibration module, we examine whether output of PC-based audiometer calibrated through auto-calibration of this paper satisfies RETSPL of IEC or not.
\end{abstract}

Key Words : Acoustic calibration, PC-based pure tone audiometer, auto-calibration module

\section{1. 서론}

순음청력검사는 주파수별 청력 손실의 정도와 유형을 평가하기 위해 임상에서 가장 널리 사용되는 중요한 표
준검사 방법 중 하나이다.

순음청력검사기는 검사 음의 생성을 위해 사용되는 다 양한 장치들 및 헤드폰의 특성에 따라 음의 크기 및 주파 수가 달라질 수 있으며, 동일한 장치도 시간이 경과함에

이 논문은 2009년도 정부(교육과학기술부)의 재원으로 한국과학재단의 지원을 받아 수행된 연구임 (No. 2009-0083825)

"교신저자 : 신범주(bjshin@pusan.ac.kr)

접수일 10년 05월 19일수정일 (1차 10년 06월 21일, 2차 10년 06월 28일)

게재확정일 10 년 07 월 06 일 
따라 그 특성이 변화할 수 있다. 따라서 검사 결과의 정 확성과 안정성을 보장하기 위해 음향 보정을 수행하는 것이 필요하다. 순음청력검사기의 음향 보정은 장치에서 발생된 음이 정확하게 목표하는 음압과 일치하는 가를 점검하고, 일치하지 않을 경우 일치할 수 있도록 조정하 는 과정을 의미한다. 이와 관련된 표준으로는 ANSI S3.6-2004[4] 규격과 ISO 389-1[5], 그리고 IEC 60645-1[6]이 있다. 보정을 위한 기준은 상기 표준들이 제공하는 순음의 주파수별 기준등가역치음압수준 (reference equipment threshold sound pressure level)에 적 합해야 한다. 그 외 점검항목으로 신호 강도의 선형성, 주 파수 정확도, 상승-하강 시간, 차폐음의 강도 등이 있다.

기존의 순음청력검사기의 음향 보정은 음압측정기를 이용하여 출력 음압 수준을 측정하고, 음압이 목표치와 다를 경우 수동으로 출력을 변경하는 방법을 사용하고 있다. 이 같이 수동으로 보정을 수행할 경우 번거로울 뿐 아니라 시간이 많이 소모되는 단점이 있다. 반면 PC 기반 순음청력검사기는 $\mathrm{PC}$ 의 사운드카드를 이용하여 소프트 웨어로 구동되기 때문에 음향 보정 과정에 사용되는 음 압측정기의 측정 값을 자동으로 인식할 수 있을 경우 보 정 과정을 자동으로 수행하는 것이 가능하다. 보정 과정 을 자동으로 수행할 경우 보정 시간을 단축할 수 있을 뿐 아니라 정확성 및 정밀성을 높일 수 있다.

본 논문에서는 선행연구에서 제시한 PC 기반 순음청 력검사기[1,2]에 자동보정기능을 추가하여 기 개발된 PC 기반 순음청력검사기의 임상적용 가능성을 평가하였다. 이를 위해서는 우선적으로 자동 보정이 가능할 수 있도 록 순음청력검사기의 출력음의 음압 수준을 측정하는 음 압측정기의 측정 값이 자동으로 보정모듈에 인지되어야 한다. 그러나 상용 음압측정기는 자동보정모듈을 위한 인 터페이스를 지원하지 않고 있다. 따라서 본 논문에서는 음압측정 값을 보정모듈에서 인지할 수 있도록 하기위하 여 PC 사운드카드를 이용한 자동보정 인터페이스를 지원 하는 음압측정기를 제작하였고, 제작된 음압측정기의 측 정 값을 이용하는 자동보정모듈을 소프트웨어로 구현하 였다. 구현된 음압측정기와 자동보정모듈로 보정된 순음 청력검사기의 출력 검사 음을 상용 정밀 음압측정기를 사용하여 측정하였고, 결과 값이 ANSI S3.6-2004[4] 표 준 규격에 적합한지를 검증하였다.

\section{2. 관련 연구}

신승원 외 4인[3]은 휴대정보단말기를 이용하여 이동 형 청력 검사 시스템에서의 음압 보정을 시도하였다. 보
정 수식을 이용하였을 때 각 $5 \mathrm{~dB} \mathrm{SPL}$ 증가에 대한 주파 수별 진폭의 $\mathrm{dB}$ 결과는 거의 $1 \mathrm{~dB}$ 내외의 선형성을 보여 준 특징이 있으나, 실험에 사용한 헤드폰이 젠하이져 $\mathrm{HD} 250$ 으로 일반적으로 사용되는 청력검사 출력장치에 포함되지 않는다. 즉 이 실험에 사용된 출력 장치는 검사 주파수에 대한 $0 \mathrm{~dB} \mathrm{HL}$ 에서의 기준역치강도가 없으므로 실제 실험한 값을 $\mathrm{HL}$ 단위로 사용하여 청력도에 표기하 기엔 무리가 있으며, 차폐 음으로 백색 잡음을 사용하였다.

최종민 외 3인[7]은 자동 보정을 지원하는 PC기반 원 격 순음청력검사기를 개발한 바 있다. 본 논문의 보정 방 법은 원격 청력검사장치를 위한 것이며, 출력 음압을 직 접 측정하는 본 논문의 방법과는 적용 분야가 구분된다.

반면 본 연구에 적용한 보정 방법은 국제표준규격에 적합한 기존의 청력검사기에 사용되는 인공 귀를 이용하 여 음압을 직접 측정하였다. 즉ANSI S3.6-2004[4]에서 규정한 순음의 출력 강도, 출력 강도의 선형성, 주파수 정 확도, 차폐 음의 출력 강도, 등 검사 음에 관한 다양한 검 증이 가능하여 정확도가 우수한 PC 기반 순음청력검사기 의 자동보정모듈을 제공할 수 있는 차별성이 있다.

\section{3. 시스템 설계 및 구현}

본 논문은 선행연구에 의해 개발된 PC 기반 순음청력 검사기 $[1,2]$ 의 기능을 확장하여 자동 보정기능을 제공하 도록 하였다. 또한 이를 효율적으로 지원하기 위해 전용 음압측정기를 개발하였다. 본 장에서는 이들의 설계 및 구현 내용을 기술한다.

\subsection{PC 기반의 음압측정기}

순음청력검사기의 자동보정을 지원하기 위해서는 발 생되는 출력 음의 주파수와 음압 수준을 측정할 수 있어 야 하며, 측정 결과 값이 자동으로 보정 소프트웨어에 전 달되어야 한다. 상용 음압측정기를 사용할 경우 측정 결 과 값을 자동으로 인식할 수 없기 때문에 본 논문에서는 $\mathrm{PC}$ 기반 음압측정기를 구현하였다.

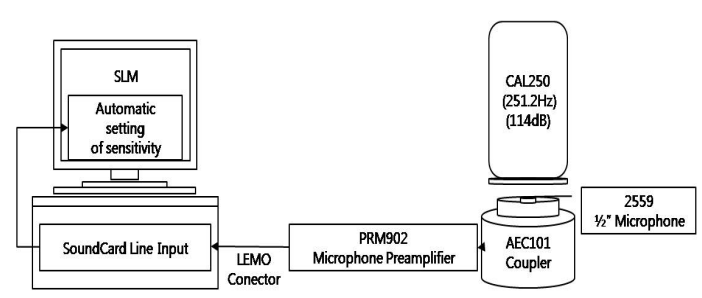

[그림 1] 자동 보정을 위한 음압측정시스템 
그림 1 에 나타낸 바와 같이 순음청력검사기의 헤드폰 을 통해 출력되는 음은 인공 귀를 통해 마이크로폰으로 전달되어 전기적 신호로 변환된다. 변환된 전기적 신호는 프리앰프를 통해 $\mathrm{PC}$ 의 라인 입력 단자로 입력되며, $\mathrm{PC}$ 는 이 신호를 처리하여 주파수 및 음압을 결정한다.

\subsection{1. 인공 귀}

커플러 또는 인공 귀는 청력검사기의 출력 장치의 출 력을 측정하는데 사용되는 표준화된 장치이다. 청력검사 기의 음향 보정기구인 인공 귀에 관한 국제적인 기준으 로 기도전도 보정에 관한 내용은 IEC 60318 규격과 IEC 60711(IEC, 1971) 규격에 의해 기준이 마련되었다.

본 논문에서는 기도전도이어폰으로 귀 덮개형 이어폰 인 TDH-39 헤드폰(Telephonics Co., USA)을 사용함으로 IEC 60318-3:1998[8]과 ANSI S3.7-1995[9]의 규격에 준 수하는 AEC101 커플러(Larson Davis Co., USA)를 사용 하였다. TDH-39 헤드폰의 출력 강도는 헤드폰을 커플러 의 상단에 위치시키고 헤드폰 위에 $500 \mathrm{~g}$ 무게의 부하를 준 후 음압측정기로 헤드폰의 출력 음을 측정하는 방법 을 사용하였다.

\subsection{2. 마이크로폰 및 프리앰프}

헤드폰에서 출력되는 음은 인공 귀를 통해 마이크에 전달되어 전기적 신호로 변환되어야 한다. IEC 60651:1979 와 ANSI S1.4-1983(R2006) 의 Type 1에 부 합하는 1/2" 정밀 무작위 입사각 마이크로폰(Larson Davis Co., USA)을 사용하였다.

프리앰프 역시 IEC 61094-4의 기준을 만족하는 1/2“ PRM 902(Larson Davis Co., USA)를 사용하였다. PRM 902 는 2559 마이크로폰과 같이 사용될 경우 감도가 250 $\mathrm{Hz}$ 에서 $12.9 \mathrm{mV} / \mathrm{Pa}$ 이고, $4.0 \mathrm{~Hz} \sim 25 \mathrm{KHz}$ 주파수 범위 에서 $\pm 2 \mathrm{~dB}$ 이내의 오차가 발생한다.

\subsection{3 음향 교정기}

음압측정시스템의 음압 보정 값을 구하기 위해 사용되 는 음향 교정기는 ANSI S1.40-2006, IEC 60942-2003 클 래스 1 기준에 부합하는 CAL 250(Larson Davis Co.)을 사용하였다. CAL 250 은 $251.2 \mathrm{~Hz}, 114 \mathrm{~dB}$ 의 순음을 발 생시키는 장치이며, 음압측정기의 보정에 사용된다.

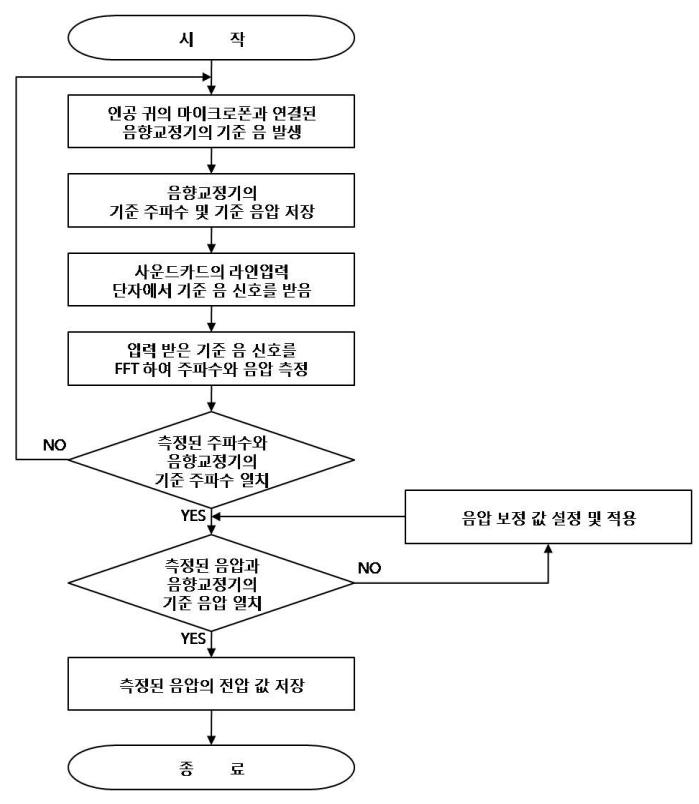

[그림 2] 음압측정 소프트웨어 동작 구조

\subsection{4 음압 측정 소프트웨어}

본 연구에서는 LabView V8.2를 사용하여 음압측정기 프로그램을 구현하였다. 구현된 음압측정기 프로그램을 그림 2에 나타내었으며, 동작 과정은 다음과 같다. 음압 측정 소프트웨어는 크게 두 가지의 기능을 제공하여야 한다. 한 가지는 음압과 주파수를 측정할 수 있어야 하며, 다른 한 가지는 기준점을 결정할 수 있는 방법이 제시되 어야 한다. 즉 음압측정기의 보정 과정이 필요하므로 사 용 전에 표준 음압과 주파수에 대한 보정을 수행해야 한 다. 보정이 완료된 후 1 초 단위로 입력 사운드를 샘플링 하고, 퓨리에 변환을 수행한 후 주파수 및 음압 수준을 분석한다. 음압 측정 소프트웨어의 사용자 인터페이스는 그림 3 과 같다. 보정을 수행할 경우 그림의 좌측 상단의 표준 음향 값을 입력하여야 하며, 음압을 측정할 경우 좌 측 하단에 인식된 음압 및 주파수가 표시된다.

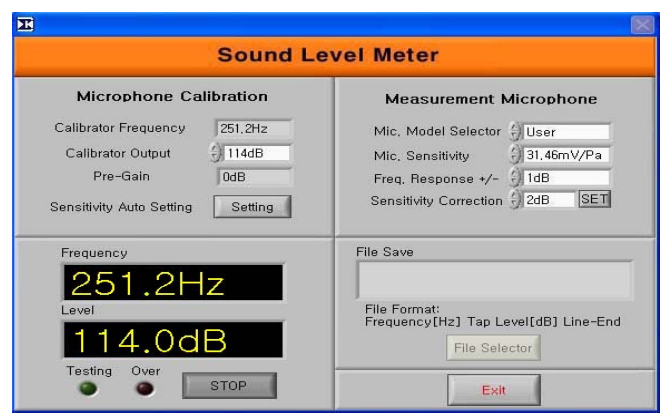

[그림 3] 음압측정기의 사용자 인터페이스 


\section{2 순음청력검사기의 자동보정}

본 논문에서는 선행연구에 의해 개발된 PC 기반의 순 음청력검사기 [1,2]에 자동보정모듈을 추가하였다. 자동보 정모듈은 출력 음압 및 주파수 값을 자동으로 인지하기 위하여 앞 절에서 기술한 전용 음압측정기를 사용하였다. 순음청력검사기의 자동보정모듈의 기능을 아래와 같다.

\subsection{1 시스템 구성 및 동작}

본 논문의 자동보정시스템의 하드웨어 구성은 그림 4 와 같다. PC 기반 순음청력검사기와 이의 출력을 증폭하 기 위한 증폭기 그리고 헤드폰으로 구성되는 순음청력검 사시스템과 출력 음을 측정하기 위해 사용되는 인공 귀, 마이크로폰, 프리앰프와 출력 음의 음압과 주파수를 측정 하는 전용 음압측정기로 구성된다. 앞 절에서 기술한 바 와 같이 인공 귀, 마이크로폰 및 프리앰프는 상용 시스템 을 사용하였다.

본 논문의 순음청력검사시스템은 $\mathrm{PC}$ 를 기반으로 하고 있고, $\mathrm{PC}$ 의 사운드카드는 일반적으로 최대 출력 음이 약 $110 \mathrm{~dB}$ 정도이기 때문에, 최대 $130 \mathrm{~dB}$ 를 출력하기 위하 여 증폭기를 사용하고 있다. 증폭기는 시리얼 포트를 통 해 전달되는 명령어를 이용해 증폭의 수준을 명령할 수 있고, $0.5 \mathrm{~dB}$ 단위의 증폭 및 감쇠할 수 있다. 증폭기를 통해 헤드폰에 전달되는 음을 청력검사에 사용하였다.

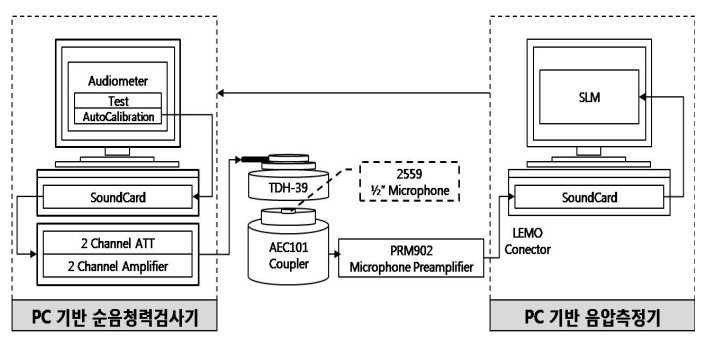

[그림 4] 자동보정시스템 구성도

순음청력검사기의 헤드폰 출력은 인공 귀와 마이크로 폰을 통해 음압측정기에 전달되고, 음압측정기에 의해 음 압 수준과 주파수 값이 측정된다. 측정값들은 순음청력검 사기의 자동보정모듈에 전달되고, 자동보정모듈은 전달 된 음압과 주파수 값을 기준으로 하여 일정량의 증폭 및 감쇠를 결정하여 새로운 움을 생성한다. 새로이 생성된 음을 출력하고, 출력 음의 측정 결과를 판정하게 된다. 이 과정은 측정된 음압 및 주파수가 원하는 수준의 오차 범 위 내에 들어올 때 까지 계속된다.

본 논문에서는 증폭기를 사용하기 때문에 PC 에서는 소프트웨어적으로 음의 최대치를 생성하여 출력하고, 증
폭기의 증폭 또는 감쇠의 정도를 조절하여 음압을 보정 하는 방법을 사용하였다.

자동보정모듈은 두 가지 인터페이스를 제공한다. 순음 에 대한 보정 인터페이스와 차폐 음에 대한 보정 인터페 이스이다. 순음은 음압 뿐 아니라 주파수의 정확도가 판 정되어야 하는 반면 차폐 음은 가우시언 백색 잡음에 $1 / 3$ 옥타브밴드를 지원하기 때문에 주파수의 정확도는 의미 가 없고 음압의 정확도가 요구되기 때문이다.

\subsection{2 순음의 보정}

순음의 경우 $125 \mathrm{~Hz} \sim 8000 \mathrm{~Hz}$ 범위내의 정해진 특 정 주파수의 순음을 $70 \mathrm{~dB} \mathrm{HL}$ 출력 강도로 사운드카드 의 라인 출력 단자로 보내면, 출력은 증폭기를 통해 $\mathrm{TDH}-39$ 헤드폰으로 신호가 전달된다. $70 \mathrm{~dB} \mathrm{HL}$ 음압 수 준을 결정하기 위해서 표 1에 나타낸 실험에 사용된 IEC 60318 커플러의 기준등가역치음압수준을 ANSI S3.6-2004[4]에 부합되게 적용하였다.

[표 1] IEC 60318 커플러의 주파수별 기준등가역치음압수준

\begin{tabular}{c|c}
\hline Frequency (Hz) & RETSPL \\
\hline 125 & 45.0 \\
\hline 250 & 25.5 \\
\hline 500 & 11.5 \\
\hline 750 & 8.0 \\
\hline 1000 & 7.0 \\
\hline 1500 & 6.5 \\
\hline 2000 & 9.0 \\
\hline 3000 & 10.0 \\
\hline 4000 & 9.5 \\
\hline 6000 & 15.5 \\
\hline 8000 & 13.0 \\
\hline
\end{tabular}

헤드폰으로 출력된 $70 \mathrm{~dB} \mathrm{HL}$ 의 순음은 헤드폰과 연 결된 커플러의 마이크로폰을 통해 앞 절에서 기술한 PC 사운드카드 라인 입력 단자로 입력 받아 음압측정기에서 주파수와 음압을 측정하였다.

모든 주파수의 보정이 완료되어 기본 보정 음압에 해 당하는 순음증폭기의 증폭 값이 결정되면 $5 \mathrm{~dB}$ 단위로 0 $\mathrm{dB}$ HL부터 각 주파수별 최대 음압 레벨의 앰프 값을 선 형적으로 설정한다. 그리고 주파수별 모든 음압의 증폭기 명령 값 결정이 완료되면 파일로 저장한다. 검사 시에는 순음청력검사기의 검사 음 재생 전 해당 검사 음의 증폭 기 값을 저장된 파일에서 읽어 증폭기에 전송하여 출력 음압을 설정한다. 그림 5 는 자동 보정 진행시 순음증폭기 의 주파수별 기본 보정 음압을 증폭기에서 증폭하여야 
할 값을 결정하기 위한 순서도를 나타낸다.

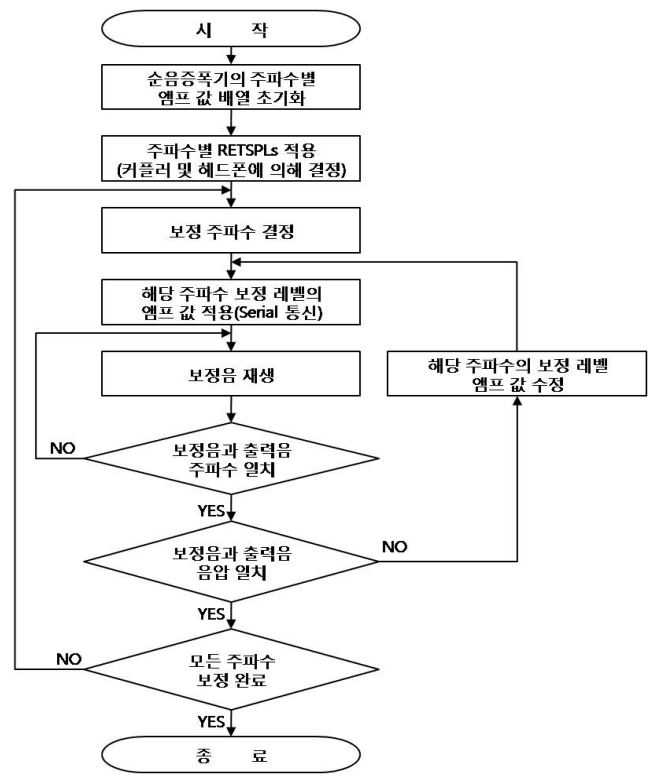

[그림 5] 보정 음압의 증폭 값 결정 순서도

그림 6 은 커플러 및 헤드폰의 종류에 따라 다른 기준 등가역치음압수준 값을 적용하는 기능과 자동보정모듈 기능 및 보정 음 정보를 보여주는 기능을 가진 자동보정 을 위한 사용자인터페이스를 나타내었다.

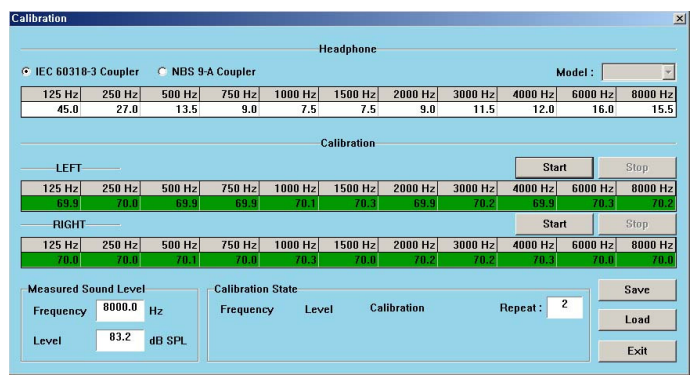

[그림 6] 자동보정모듈의 사용자 인터페이스

\subsection{3. 차폐 음의 보정}

피검자의 양쪽 귀의 청력 차이가 어느 수준이상일 경 우 반대 귀를 통해 듣는 경우를 방지하기 위하여 순음청 력검사기에서 반대쪽 귀에 차폐 음을 출력하여야 한다. 차폐 음은 중심 주파수를 기준으로 $1 / 3$ 옥타브의 주파수 만 존재하는 잡음이다. 차폐 음은 순음의 기준등가역치음 압수준에 각 주파수별 차폐 음의 보정 값을 추가해야 한 다. 표 2는 ISO 389-4:1994[10]의 규정에서 TDH-39 헤드 폰을 사용하여 $1 / 3$ 옥타브밴드 차폐 음으로 적정 차폐를
이루기 위해 순음의 기준음압강도에 추가되는 보정 값을 나타낸다.

[표 2] 차폐 음의 주파수별 추가 보정 수치

\begin{tabular}{c|c}
\hline Frequency (Hz) & Correction Factor \\
\hline 125 & 4 \\
\hline 250 & 4 \\
\hline 500 & 4 \\
\hline 750 & 5 \\
\hline 1000 & 6 \\
\hline 1500 & 6 \\
\hline 2000 & 6 \\
\hline 3000 & 6 \\
\hline 4000 & 5 \\
\hline 6000 & 5 \\
\hline 8000 & 5 \\
\hline
\end{tabular}

\section{4. 시험 및 결과}

\section{1 시험 환경}

구현된 자동보정모듈의 동작을 검증하기 위해 다음의 환경에서 시험하였다. 자동보정모듈을 가진 $\mathrm{PC}$ 기반 순 음청력검사기는 Intel Core2 Duo E7400 $2.8 \mathrm{GHz}$ 프로세 서, Audiophile 2496사운드카드를 지원하는 Windows XP 기반 $\mathrm{PC}$ 를 사용하였다. 헤드폰은 $10 \Omega \mathrm{TDH}-39$ 를 사용하 였다. 보정에 사용되는 인공 귀, 마이크로폰, 마이크로폰 프리앰프는 Larson Davis 사의 제품을 사용하였고, 보정 용 음압측정기는 Intel Pentium D 3.0G 프로세서 및 M-Audio사의 Audiophile 2496 사운드카드를 장착한 Windows XP의 $\mathrm{PC}$ 를 사용하였다. 보정이 완료된 순음청 력검사기의 출력 음의 정확성을 판단하기 위하여 $\mathrm{AEC} 101$ 커플러와 $1 / 3$ 옥타브 밴드에 대한 대역폭 준수 여부를 판단하는 정밀 음압측정기인 Larson Davis 사의 System 824 모델을 사용하였다. 모든 음향학적인 측정은 ANSI S3.1-1999(R2008)[11]를 준수하는 방음실(ECKEL C24)에서 수행하였다.

음압이 제대로 출력되는지 검증하기 위해 순음의 출력 강도, 출력 강도의 선형성, 주파수 정확도를 측정하였으 며, 차폐 음은 $1 / 3$ 옥타브밴드를 지원하는 협대역 잡음이 므로 출력 강도만을 측정하였다.

\section{2 시험 결과}

\subsection{1 순음의 출력 강도}

$\mathrm{PC}$ 기반 순음청력검사기에서 자동보정모듈을 사용하 여 TDH-39 헤드폰에서 출력되는 순음을 $125 \mathrm{~Hz} \sim 8000$ 
$\mathrm{Hz}$ 범위에서 $70 \mathrm{~dB} \mathrm{HL}$ 기준으로 보정하였다. 표 3은 순 음 보정 후 결과를 나타낸다. 모든 주파수에서 출력 강도 는 우측의 경우 $70 \mathrm{~dB} \mathrm{HL}$ 에서 $-0.4 \sim 0.6 \mathrm{~dB}$ 범위 내에 존재하였고, 좌측의 경우는 $70 \mathrm{~dB} \mathrm{HL}$ 에서 $-0.5 \sim 0.3 \mathrm{~dB}$ $\mathrm{HL}$ 범위 내에 존재하였고, 동일 주파수에서 좌, 우측의 출력 강도의 오차는 $0.0 \sim 0.7 \mathrm{~dB} \mathrm{HL}$ 로 측정되었다.

[표 3] 순음의 출력 강도

\begin{tabular}{|c|c|c|c|c|c|c|}
\hline \multirow{2}{*}{$\begin{array}{c}\text { Frequency } \\
(H z)\end{array}$} & \multicolumn{2}{|c|}{$\begin{array}{c}\text { Measured } \\
\text { SPL }\end{array}$} & \multicolumn{2}{|c|}{ Hearing level } & \multicolumn{2}{c|}{ Deviation } \\
\cline { 2 - 7 } & Right & Left & Right & Left & Right & Left \\
\hline 125 & 115.2 & 114.8 & 70.2 & 69.8 & 0.2 & -0.2 \\
\hline 250 & 95.8 & 95.8 & 70.3 & 70.3 & 0.3 & 0.3 \\
\hline 500 & 81.6 & 81.5 & 70.1 & 70.0 & 0.1 & -0.0 \\
\hline 750 & 77.9 & 78.1 & 69.9 & 70.1 & -0.1 & 0.1 \\
\hline 1000 & 77.0 & 76.8 & 70.0 & 69.8 & -0.0 & -0.2 \\
\hline 1500 & 76.3 & 76.6 & 69.8 & 70.1 & -0.2 & 0.1 \\
\hline 2000 & 78.9 & 79.1 & 69.9 & 70.1 & -0.1 & 0.1 \\
\hline 3000 & 79.6 & 79.8 & 69.6 & 69.8 & -0.4 & -0.2 \\
\hline 4000 & 79.1 & 79.0 & 69.6 & 69.5 & -0.4 & -0.5 \\
\hline 6000 & 85.9 & 85.5 & 70.4 & 70.0 & 0.4 & -0.0 \\
\hline 8000 & 83.6 & 83.1 & 70.6 & 70.1 & 0.6 & -0.1 \\
\hline
\end{tabular}

\subsection{2 출력 강도의 선형성}

본 논문의 $\mathrm{PC}$ 기반 순음청력검사기의 측정 주파수 $125 \mathrm{~Hz} \sim 8000 \mathrm{~Hz}$ 범위에서의 순음의 최대 출력은 90 $\sim 120 \mathrm{~dB}$ HL이다. 선형성은 순음의 최대 출력에서 $5 \mathrm{~dB}$ 단위로 감소시켜 음압측정기의 바닥 잡음(noise floor)에 도달할 때까지 측정하였다.

측정주파수 범위의 최대 출력 강도에서 $50 \mathrm{~dB} \mathrm{HL}$ 까 지는 양측 헤드폰 모두 $-0.3 \sim-0.1 \mathrm{~dB}$ 의 오차가 관찰되 었고, 그 이하의 출력 강도에서부터 바닥 잡음까지는 최 대 $-0.9 \mathrm{~dB}$ 의 오차가 관찰되었다. $\mathrm{PC}$ 기반의 순음청력검 사기의 출력 강도 선형성 측정 결과는 그림 7 과 같다.

\subsection{3 주파수 정확도}

측정 주파수의 정확도는 $125 \mathrm{~Hz}$ 에서 우측 헤드폰에서 $0.2 \mathrm{~Hz}$ 가 벗어나 $0.16 \%$ 의 오차가 관찰되었고, $1000 \mathrm{~Hz}$ 와 $1500 \mathrm{~Hz}$ 에서는 양측 모두 $0.1 \mathrm{~Hz}$ 가 벗어나 각각 $0.01 \%$, $0.007 \%$ 의 오차가 관찰되었다. 그 외 모든 주파수에서는 오차가 관찰되지 않았다. $\mathrm{PC}$ 기반 순음청력검사기의 측 정 주파수 정확도 측정 결과는 표 4와 같다.
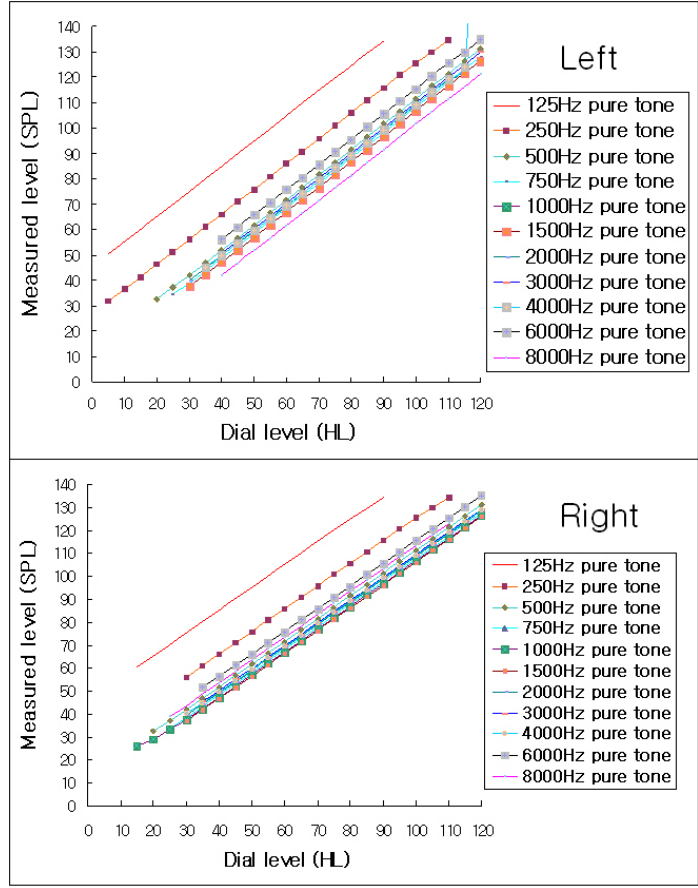

[그림 7] 순음 출력 강도의 선형성

[표 4] 순음의 주파수 정확도

\begin{tabular}{|c|c|c|c|c|}
\hline \multirow{2}{*}{$\begin{array}{c}\text { Frequency } \\
(\mathbf{H z})\end{array}$} & \multicolumn{2}{|c|}{ Measured Frequency } & \multicolumn{2}{c|}{ Deviation } \\
\cline { 2 - 5 } & Right & Left & Right & Left \\
\hline 125 & 125.2 & 125.0 & 0.2 & 0.0 \\
\hline 250 & 250.0 & 250.0 & 0.0 & 0.0 \\
\hline 500 & 500.0 & 500.0 & 0.0 & 0.0 \\
\hline 750 & 750.0 & 750.0 & 0.0 & 0.0 \\
\hline 1000 & 1000.1 & 1000.1 & 0.1 & 0.1 \\
\hline 1500 & 1500.1 & 1500.1 & 0.1 & 0.1 \\
\hline 2000 & 2000.0 & 2000.0 & 0.0 & 0.0 \\
\hline 3000 & 3000.0 & 3000.0 & 0.0 & 0.0 \\
\hline 4000 & 4000.0 & 4000.0 & 0.0 & 0.0 \\
\hline 6000 & 6000.0 & 6000.0 & 0.0 & 0.0 \\
\hline 8000 & 8000.0 & 8000.0 & 0.0 & 0.0 \\
\hline
\end{tabular}

\subsection{4 차폐 음}

순음청력검사기의 측정 주파수 $125 \mathrm{~Hz} \sim 8000 \mathrm{~Hz}$ 범 위에서 측정된 협대역 잡음의 음압 강도는 청력검사기 출력 강도에 순음의 주파수별 기준등가역치음압수준을 더하고 여기에 협대역 잡음의 보정 값을 추가한 값이다. 측정된 협대역 잡음의 음압 강도는 허용 오차 범위 -3 $5 \mathrm{~dB}$ 이내에 존재해야 한다. 
[표 5] 차폐 음의 출력 강도

\begin{tabular}{|c|c|c|c|c|}
\hline \multirow{2}{*}{$\begin{array}{c}\text { Frequency } \\
(\mathbf{H z})\end{array}$} & \multicolumn{2}{|c|}{ Measured SPL } & \multicolumn{2}{c|}{ Hearing level } \\
\cline { 2 - 5 } & Right & Left & Right & Left \\
\hline 125 & 121.6 & 118.3 & 72.6 & 69.3 \\
\hline 250 & 100.4 & 99.9 & 70.9 & 70.4 \\
\hline 500 & 85.7 & 85.9 & 70.2 & 70.4 \\
\hline 750 & 82.6 & 83.0 & 69.6 & 70.0 \\
\hline 1000 & 82.7 & 82.6 & 69.7 & 69.6 \\
\hline 1500 & 81.9 & 81.9 & 69.4 & 69.4 \\
\hline 2000 & 84.9 & 85.2 & 69.9 & 70.2 \\
\hline 3000 & 84.4 & 84.6 & 68.4 & 68.6 \\
\hline 4000 & 84.2 & 84.4 & 69.7 & 69.9 \\
\hline 6000 & 88.2 & 88.5 & 67.7 & 68.0 \\
\hline 8000 & 89.8 & 89.2 & 71.8 & 71.2 \\
\hline
\end{tabular}

표 5에 측정된 차폐 음 출력 강도의 결과를 나타내었 다. 측정 주파수 범위에서 우측 헤드폰의 경우 -2.3 $2.6 \mathrm{~dB} \mathrm{HL}$ 의 오차 범위를 가지고 좌측 헤드폰의 경우 $-2.0 \sim 1.2 \mathrm{~dB} \mathrm{HL}$ 의 오차 범위를 나타내었다.

\section{3 평가}

자동보정모듈을 이용한 출력 강도의 교정 범위는 모든 측정 주파수에서 $\pm 0.3 \mathrm{~dB}$ 이내의 범위에 포함되었다. 순 음의 측정 결과는 모든 측정 주파수에서 양측 헤드폰의 출력 강도의 교정 오차는 $1 \mathrm{~dB} \mathrm{HL}$ 이내로 아주 우수하였 다. 순음에서 출력 강도의 선형성은 $50 \mathrm{~dB} \mathrm{HL}$ 까지는 양 측 헤드폰 모두 $-0.3 \sim-0.1 \mathrm{~dB}$ 의 오차가 관찰되었고, 그 이하에서 잡음 바닥까지는 $-0.9 \mathrm{~dB}$ 정도의 오차가 관찰되 었다. 이는 환경 잡음 때문인 것으로 판단된다. 일반적으 로 감쇠기의 선형성은 최대 강도에서 $70 \mathrm{~dB} \mathrm{HL}$ 까지 측 정하거나, $70 \mathrm{~dB} \mathrm{HL}$ 에서 $5 \mathrm{~dB}$ 단계로 강도를 증가하고 감쇠시켜 측정한다. 이 이하의 강도로 선형성을 분석하는 것은 음압측정기의 바닥 잡음에 도달하거나 측정하는 검 사실 내의 잡음에 영향을 받기 때문이다.

협대역 잡음의 출력 강도는 우측 헤드폰의 경우 -2.3 $\sim 2.6 \mathrm{~dB}$ 범위 내에 존재하고, 좌측 헤드폰의 경우 -2.0 $\sim 1.2 \mathrm{~dB}$ 범위 내에 존재하였다. ANIS S3.6-2004[4]에서 는 $125 \mathrm{~Hz} \sim 8000 \mathrm{~Hz}$ 범위의 순음의 경우 출력 강도는 기준등가역치음압수준에서 $\pm 2.5 \mathrm{~dB}$ 이내, 출력 강도의 선형성은 $5 \mathrm{~dB}$ 단계로 측정할 때 $\pm 1.0 \mathrm{~dB}$ 이내, 주파수의 정확도가 $1 \%$ 이내로 규정하고 있다. $1 / 3$ 옥타브 밴드로 필터링한 협대역 잡음의 경우는 순음의 기준등가역치음 압수준에 보정 값을 더한 강도와 비교하여 $-3 \sim 5 \mathrm{~dB}$ 범 위 내에 존재해야 한다고 규정하고 있다. 이 보다 오차가
작은 경우에 특별한 보정을 실시하지 않아도 된다.

최종민 외 3 인[7]은 자동보정모듈을 이용하여 출력 강 도에서 $1 \mathrm{~dB}$ 이내의 보정 오차로 우수한 결과를 얻었으 나, 출력 강도의 선형성, 주파수 정확도, 차폐 음의 출력 강도에 관한 언급은 없었다.

이상과 같이 본 논문의 자동보정모듈을 통해 생성된 순음과 협대역 잡음의 음향학적 특성을 검증한 결과 모 든 실험에서 ANSI S3.6-2004[4]의 기준에 부합할 뿐만 아니라 그 이상의 성능 특성을 나타냄을 볼 수 있었다.

\section{5. 결론 및 향후 계획}

본 논문은 자동보정기능을 제공하기 위해 전용 음압측 정기를 개발하고, 기존의 PC 기반 순음청력검사기의 소 프트웨어를 확장하여 자동보정기능을 지원하는 순음청력 검사기로 확장하였다. 구현된 음압측정기와 자동보정기 능을 통해 PC 기반 순음청력검사기를 보정하고, 이를 상 용 정밀 음압측정기를 사용하여 검증하였다. 검증 결과 측정된 순음의 출력 강도, 출력 강도의 선형성, 주파수 정 확도, 그리고 협대역 잡음의 출력 강도 등의 모든 음향학 적 측정 항목에서 ANIS S3.6-2004[4] 규격을 완벽하게 준수함을 확인할 수 있었다.

따라서 본 논문의 자동보정모듈을 적용할 경우 기 개 발된 PC 기반 순음청력검사기는 임상에서 사용 가능한 수준임을 알 수 있었다.

\section{참고문헌}

[1] 김진동, 신범주, 전계록, 왕수건, "다중모드 지원 자 동차폐 순음청력검사 시스템 개발”, 한국산학기술학 회논문지 제 10 권 제6호, 2009.7.

[2] 강덕훈외 6 인, "PC 기반의 SISI 검사 소프트웨어 개 발”, 한국산학기술학회논문지, 제 11권 제4호, 2010.4 .

[3] 신승원외 4인, “음압 보정을 통한 이동형 청력 검사 시스템의 구현", 전기학회논문지 제56권 6호, 2007.

[4] ANSI(American National Standard Institute) S3.6-2004, "American National Standard Specification for audiometers", 2004.

[5] ISO(International Organization for Standardization) 389-1 :1998, Acoustics - Reference zero for the calibration of audiometer equipment - Part 1 : Reference equivalent threshold sound pressure levels for pure tone and supra-aural earphones.

[6] IEC(International Electrotechnical Commission) 60645-1 
:2001, Electroacoustics - Audiological Equipment Part 1: Pure-Tone Audiometers

[7] Jong Min Choi et. al., "PC-Based Tele-Audiometry", Telmedicine And E-Health Vol. 13 No 5, 2007.

[8] IEC 60318-3:1998-08, Electroacoustics - Simulators of human head and ear - Part 3: Acoustic coupler for the calibration of supra-aural earphones used in audiometry.

[9] ANSI S3.7-1995(R2003), American National Standard Method for Coupler Calibration of Earphones.

[10] ISO 389-4:1994, Acoustics - Reference zero for the calibration of audiometric equipment - Part 4: Reference levels for narrow-band masking noise.

[11] ANSI S3.1-1999 (R2008), Maximum Permissible Ambient Noise Levels for Audiometric Test Rooms

\section{김 진 동(Jin Dong Kim)}

[정회원]

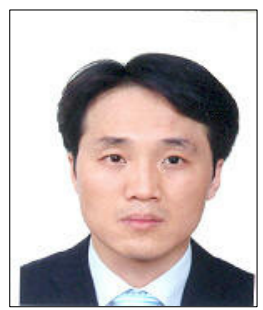

- 2006년 2월 : 부산대학교 대학원 의학과(의학석사)

- 2010년 2월 : 부산대학교 대학원 의공학협동과정 박사과정수료

- 1999년 5월 현재 : 부산대학 교병원 이비인후과

<관심분야>

신호처리, 생체계측, 의공학

\section{강 덕 훈(Deok Hun Kang)}

[준회원]

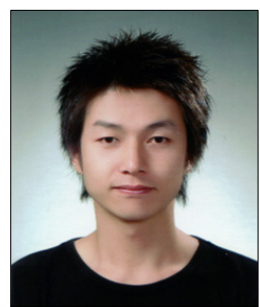

- 2009년 8월 현재 : 부산대학 교 대학원 바이오메디컬공학과 (공학석사과정)

<관심분야>

영상신호처리, 메디컬 소프트웨어 응용

\section{송 복 득(Song Bok Deuk)}

[정회원]

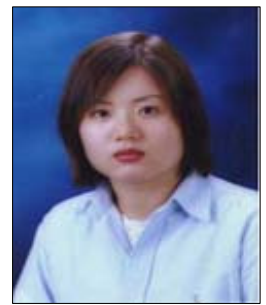

- 2004년 2월 : 동서대학교 소프트 웨어전문대학원 소프트웨어학과 (공학석사)

- 2009년 8월 현재 : 부산대학 교 대학원 바이오메디컬공학과 (공학박사과정)

<관심분야>

영상신호처리, 머신 비젼, 메디컬 소프트웨어 응용

\section{이 일 우(Il Woo Lee)}

[정회원]

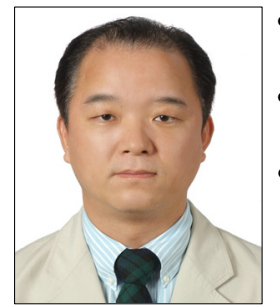

- 1999년 2월 : 부산대학교 대학원 의학과(의학석사)

- 2005년 2월 : 부산대학교 대학원 의학과(의학박사)

- 2002년 3월 현재 : 부산대학 교 의학전문대학원 부교수

<관심분야>

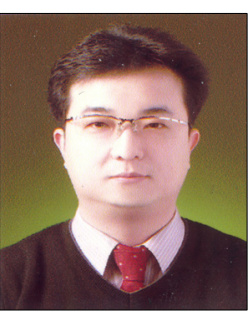

<관심분야>
- 2001년 8월 : 부산대학교 대학원 의학과(의학석사)

- 2010년 2월 : 부산대학교 대학원 의학과(의학박사)

- 2009년 3월 현재 : 부산대학 교 의학전문대학원 조교수 


\section{권 순 복(Soon Bok Kwon)}

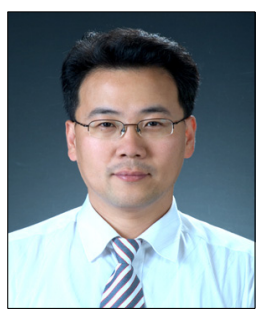

- 2000년 2월 : 대구대학교 재활과 학대학 언어치료전공(석사)

- 2006년 2월 : 부산대학교 대학원 의공학협동과정 (공학박사)

- 2007년 3월 현재 : 부산대학 교 인문대학 언어정보학과 조교 수

<관심분야>

음성장애/청각장애(인공와우언어재활)

\section{전 계 록(Gye Rok Jeon)}

[정회원]

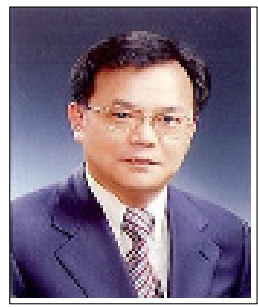

- 1982년 2월 : 부산대학교 대학원 전자공학과 (공학석사)

- 1993년 2월 : 동아대학교 대학원 전자공학과 (공학박사)

- 1985년 3월 현재 : 부산대학 교 의과대학 교수

<관심분야>

생체신호계측, 생체시스템 모델링

신 범 주(Bum Joo Shin)

[정회원]

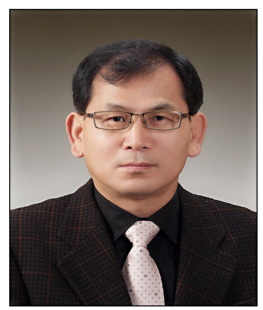

- 1991년 2월 : 경북대학교 대학원 컴퓨터공학과(공학석사)

- 1998년 8월 : 경북대학교 대학원 컴퓨터공학과(공학박사)

- 1987년 3월 2002년 2월 :한국 전자통신연구원 책임연구원

- 2006년 3월 현재 :부산대학교 바이오메디컬공학과 부교수

<관심분야>

센서시스템, 메디컬 소프트웨어 응용
왕 수 건(Soo Geun Wang)

[정회원]

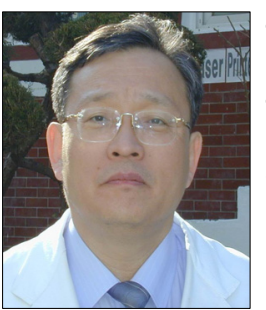

- 1981년 2월 : 부산대학교 대학원 의학과(의학석사)

- 1988년 2월 : 부산대학교 대학원 의학과(의학박사)

- 1987년 10월 현재 : 부산대학 교 의학전문대학원 교수 